\title{
Influence of the coupling between the mechanical characteristics and the welding conditions by the FSSW process: case of the bi-material aluminum-steel
}

\author{
H. Mekri, B. Bouchouicha, A. Miloudi \\ University of DjillaliLiabes, SidiBelAbbès, Algeria. \\ mekribichem@hotmail.fr,benattou_b@yahoo.fr,miloudidz@yahoo.fr \\ H. Christophe, A. Imad \\ University of Lille 1, France \\ christophe.herbelot@polytech-lille.fr, abdellatifimad@polytech-lilll.fr
}

ABSTRACT. The present study investigates the effect of joining parameters on the mechanical characteristics of dissimilar friction stir spot welding (FSSW) between aluminum alloys and galvanized steel. Mechanical performance has been evaluated by shear and microhardness testing. A macrostructural examination has revealed the creation of mechanical interlocking in the $\mathrm{Al}$ steel connections. Shear failure load has increased with increasing both tool rotational speed and plunge depth for all FSSW connections. Higher plunge depth has improved the mechanical interlocking between lower and upper sheet due to the formation of hook.

KEYwORDS. Assembly; Friction stir spot welding; Aluminum alloy; Galvanized steel; Mechanical properties.

\section{OPEN ACCESS}

Citation: Mekri, H., Bouchouicha, B., Miloudi, A., Christophe, H., Imad, A., Influence of the coupling between the mechanical characteristics and the welding conditions by the FSSW process: case of the bi-material aluminum-steel, Frattura ed Integrità Strutturale, 46 (2018) 62-72.

Received: 07.03 .2018

Accepted: 31.05 .2018

Published: 01.10.2018

Copyright: (C) 2018 This is an open access article under the terms of the CC-BY 4.0, which permits unrestricted use, distribution, and reproduction in any medium, provided the original author and source are credited.

\section{INTRODUCTION}

$\mathrm{T}$ he increasing demand for energy saving as well as environmental issues in different industry sectors has led to the necessity of using lightweight alloys and advanced high strength steels. Such interest has created the need to develop reliable joining technologies which can enable multilateral design and low cost fabrication processes [1,2]. The assembly between two different materials $(\mathrm{Al} / \mathrm{Steel}, \mathrm{Al} / \mathrm{Cu}, \ldots)$ by conventional technologies of welding by fusion is rather complicated and can be due completely difficult to their various physical and chemical properties, in particular with the difference in the cast iron temperatures and with mutual solubility. Furthermore, these processes have the disadvantage of severe heating and cooling cycles which can result in the formation of brittle cast structure, porosity and large amounts of intermetallic phases $\left(\mathrm{Fe}_{\mathrm{n}} \mathrm{Al} \mathrm{m}\right)$ that have a detrimental effect on the mechanical properties of the joint, multiaxial fatigue, fatigue properties and fracture mechanism of load [16, 17, 29, 30]. Brazing has also been used as a tentative process to join aluminum and steel. Strong joints have been formed using a eutectic Al-Si brazing alloy. However, holding time must be kept as minimum as possible to avoid the formation of a second, more fragile $\mathrm{Fe}_{\mathrm{n}} \mathrm{Al}_{\mathrm{m}}$ intermetallic layer [18]. Other processes 
used for joining Al/steel, particularly in the automotive industry, are self-pierce riveting [24], mechanical clinching as well as adhesive bonding coupled with another joining technique [25]. By using solid state welding processes, such as friction welding [19, 20, 27], diffusion bonding [21] magnetic pressure/ pulse seam welding [22] and ultrasonic welding [23], sound $\mathrm{Al} /$ steel joints have been produced. However, these processes have several disadvantages such as longer joining times as well as geometry requirements, among others. Although the formation of the intermetallic phases is kept as minimum as possible due to the minimised energy input, a very thin layer of $\mathrm{Fe}_{\mathrm{n}} \mathrm{Al}_{\mathrm{m}}$ phases is still formed at the $\mathrm{Al} /$ steel interface in all aforementioned processes. The Friction Stir Welding (FSW) process was developed by TWI in 1991 [10], as a novel method for joining Al-alloys and, since that time, the welding process has been employed when fabricating non-ferrous alloys (aluminum, titanium, magnesium, zinc and copper alloys), as well as steel and thermoplastic substrates having thicknesses from 1 to $50 \mathrm{~mm}$. The FSSW process is a variant of the FSW technique [13, 28], in which the tool is not traversed and instead creates the joint by plunging into and retracting out the tool of the overlapping sheets [14, 15]. The influence of welding parameters on the failure load properties of Al/Al-alloy friction stir spot welds has been examined at length [5, 11, 12]. A schematic illustration of the FSSW process joining two metal sheets is shown in Fig.1. As shown in this figure, this process consists of three stages. First a rotating tool $\mathrm{R}_{\mathrm{S}}$ with a threaded probe is plunged into the upper sheet with a clockwise rotation rate $R_{S}$ of $1000,1400,2000 \mathrm{rpm}$ and a plunge rate $V_{p}$ of $16 \mathrm{~mm} / \mathrm{min}$ and with penetration depth of length $\mathrm{D}_{\mathrm{p}}(\mathrm{mm})$. The process control is a displacement (position) control. Second when a shoulder contact the upper sheet, the force control (load) is used, characterised by the tool being driven into the specimen at a rate controlled by the axial force on the tool. The plunging continues as the axial force F increases until a predetermined value F of $1400 \mathrm{Kg}$ is reached. The force is held constant for a 2 seconds dwell time to generate a frictional heat. The heated and soften material, is plastically deformed and a solid state bond is made between the sheets. After which, thirdly the tool is retracted with a withdrawal rate $V_{w}$ of $100 \mathrm{~mm} / \mathrm{min}$ [4], each parameter in this study is characterised with the software MODDE 5.0 (Modeling and Design) [26] is used for the model elaboration and the statistical analysis of the experimental design.

The present work concerns on the study of rupture of a FSSW assembly which consists of single lap of two different thin sheets of aluminum alloy 6061 T5 and galvanized steel having thickness $1.7 \mathrm{~mm}$.

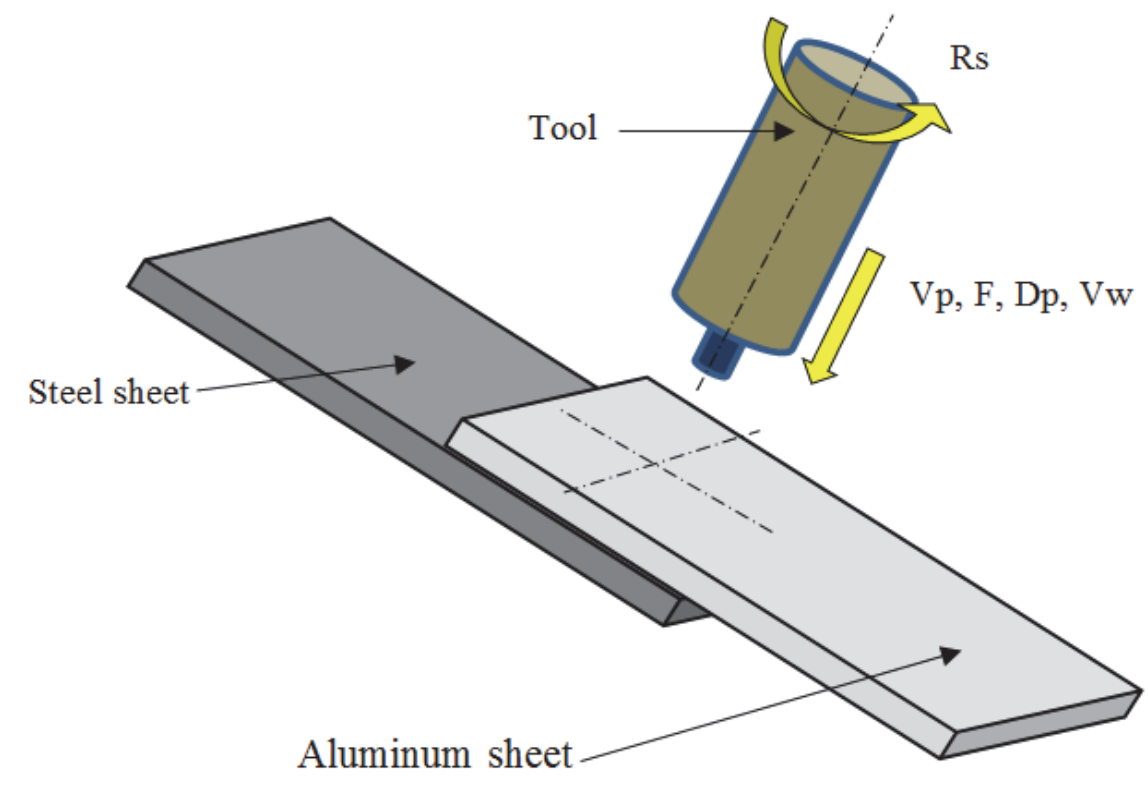

Figure 1: Schematic illustration of stages of FSSW process.

\section{MATERIALS AND COMPOSITION}

ommercial grade AA 6061 alloy and galvanized steel sheets of $1.7 \mathrm{~mm}$ thick were used as the starting materials. AA 6061 is in the T5 condition in the as received condition and a galvanized steel sheet. Their nominal chemical compositions are presented in Tab. 1. 


\begin{tabular}{ccccccccccccc}
\hline Materials & $\mathrm{Si}$ & $\mathrm{Fe}$ & $\mathrm{Cu}$ & $\mathrm{Mn}$ & $\mathrm{Mg}$ & $\mathrm{Cr}$ & $\mathrm{Zn}$ & $\mathrm{Ti}$ & $\mathrm{C}$ & $\mathrm{P}$ & $\mathrm{Alt}$ & $\mathrm{S}$ \\
6061-T5 & 0.6 & 0.30 & 0.10 & 0.10 & 0.60 & 0.05 & 0.1 & 0.1 & $\ldots .$. & $\ldots .$. & $\ldots .$. & $\ldots .$. \\
Galvanized Steel & 0.5 & Rest & $\ldots .$. & 1 & $\ldots \ldots$ & $\ldots .$. & $\ldots \ldots$ & $\ldots .$. & 0.1 & 0.03 & 0.025 & 0.025 \\
\hline
\end{tabular}

Table 1: Chemical compositions of AA 6061-T5 and Galvanized steel.

\section{EXPERIMENTAL METHODS}

\section{The welding machine}

7 he basic principle of process FSSW is carried out on a modified conventional milling machine. This machine is largely used for the operations of machining in industry. It is one of the first machines used to carry out FSW.

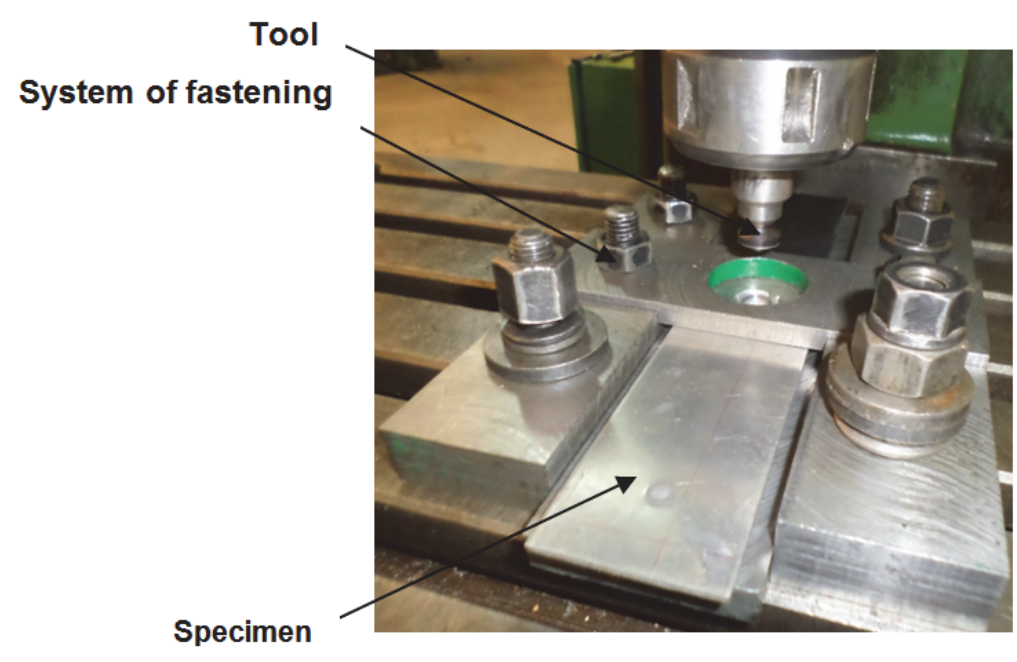

Figure 2: Clamping of the joint configuration on the FSSW machine.

It can apply up to $360 \mathrm{KN}$ of axial load [5], which makes it possible to weld plates of aluminium alloys until $15 \mathrm{~mm}$ thickness. The tool of welding and the system of fastening is shown in Fig.2.

\section{Joint configuration, tool and its geometry}

The main dimensions of the tool made of height strength steel are given in Fig. 3. The fixed probe has a diameter of 5 mm and a length of $1.8 \mathrm{~mm}$. The flat shoulder has a diameter of $10 \mathrm{~mm}$. These geometrical characteristics were selected on the basis of preliminary tests developed by several researchers [5-8].

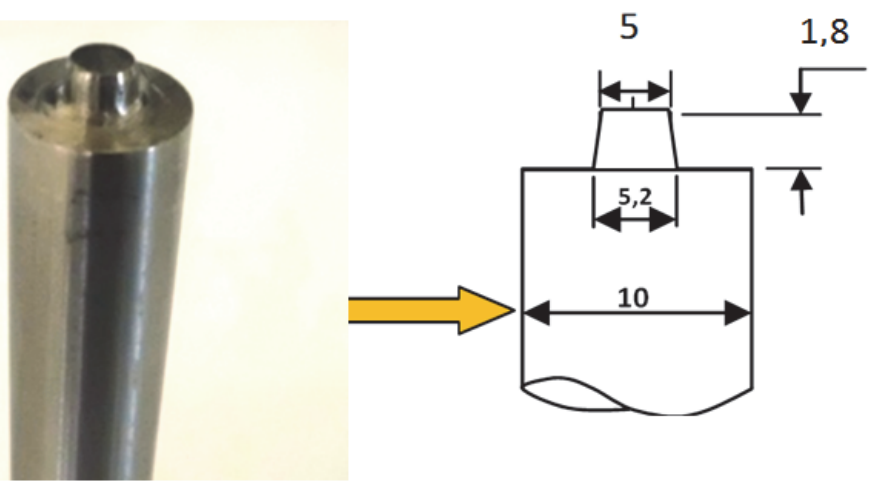

Figure 3: Tool geometry and processing variables 


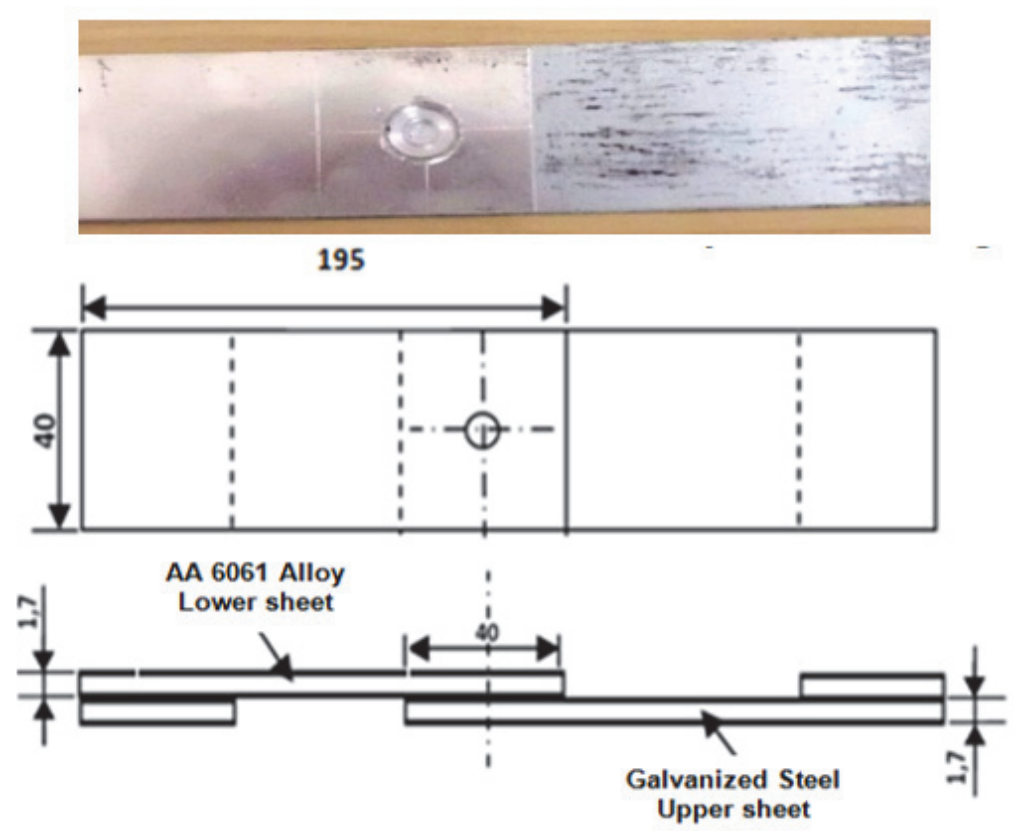

Figure 4: Dimensions in mm of FSSW specimens.

Dimensions of the assembly in Fig. 4 are fixed according to relations $\mathrm{W} / \mathrm{H}=2$ where $\mathrm{W}$ is the width of the specimen and $\mathrm{H}$ the distance between the center of the exit hole and the free edge of the substrate in the longitudinal direction [9]. The thickness of substrates is 1.7 millimetres and shims of same thickness bulk material were used for the specimens to maintain alignment in shear tensile testing.

The monotonic tensile tests were carried out on an electromechanical tensile testing machine. The crosshead displacement speed is set at a rate $0.6 \mathrm{~mm} \mathrm{~min}^{-1}$. Spacer was used during testing to compensate for the offset created by the lap joint.

\section{The welding parameters}

The welding parameters used for all FSSW welds are listed in Tab. 2. The downward and upward welding speed ranged at $16 \mathrm{~mm} / \mathrm{min}$. The rotational speed of the tool ranged from 1000 to $2000 \mathrm{rpm}$ and the penetration depth 1.9 to $2.7 \mathrm{~mm}$.

\begin{tabular}{|c|c|c|c|c|c|c|c|c|c|}
\hline Tool rotational speed (rpm) & 1000 & 1400 & 2000 & 1000 & 1400 & 2000 & 1000 & 1400 & 2000 \\
\hline Penetration depth (mm) & & 1.9 & & & 2.3 & & & 2.7 & \\
\hline
\end{tabular}

Table 2: Welding parameters of FSSW.

\section{RESULTS AND DISCUSSION}

\section{Temperature profile}

he layout of thermocouples is shown in Fig.5. The transient temperatures from the thermocouples were recorded. The thermocouple placed approximately under the center of stir zone.

In Fig. 6 a maximum temperature of the experimental test that it was detected for a penetration of $1.9 \mathrm{~mm}$ was approximately $260^{\circ} \mathrm{C}$ for the sample with tool rotating speed of $2000 \mathrm{rpm}$ and the minimal is détected with $1000 \mathrm{rpm}$ at $110^{\circ} \mathrm{C}$. The maximum temperature of experimental result that detected for penetration of 2.3 mm was approximately $322^{\circ} \mathrm{C}$ for the sample with tool rotating speed of $2000 \mathrm{rpm}$, and the minimal is detected with $1000 \mathrm{rpm}$ at $175^{\circ} \mathrm{C}$. The maximum temperature of experimental test that was detected for penetration of $2.7 \mathrm{~mm}$ was approximately $455^{\circ} \mathrm{C}$ for the sample with tool rotating speed of $2000 \mathrm{rpm}$, and the minimal is detected with $1000 \mathrm{rpm}$ at $287^{\circ} \mathrm{C}$. The temperature profiles have a uniform plot during the welding process which is trending symmetrically toward the peak of thermal cycles, and dropping axisymmetrically after passing through the maximum temperature. 


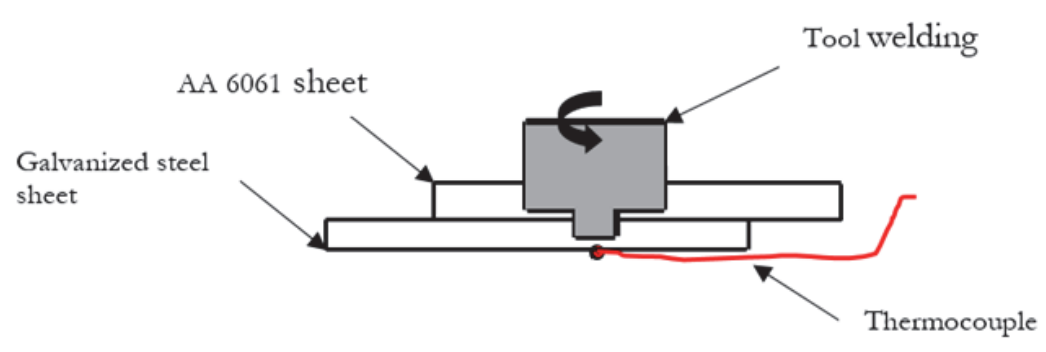

Figure 5: Thermocouples placement in FSSW.

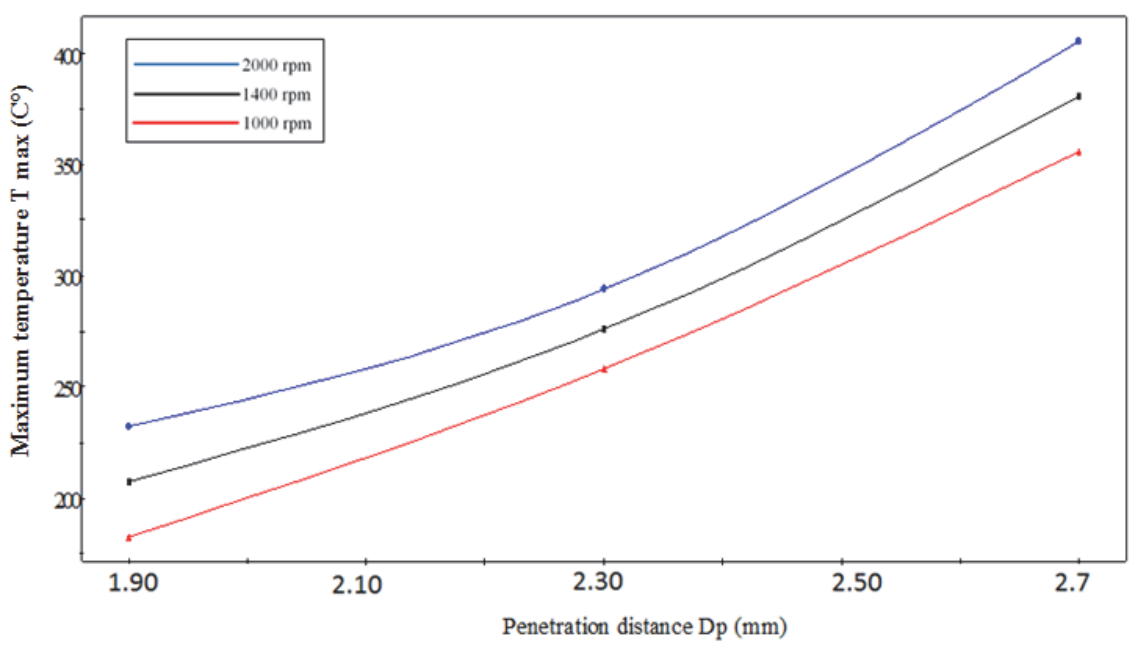

(a)

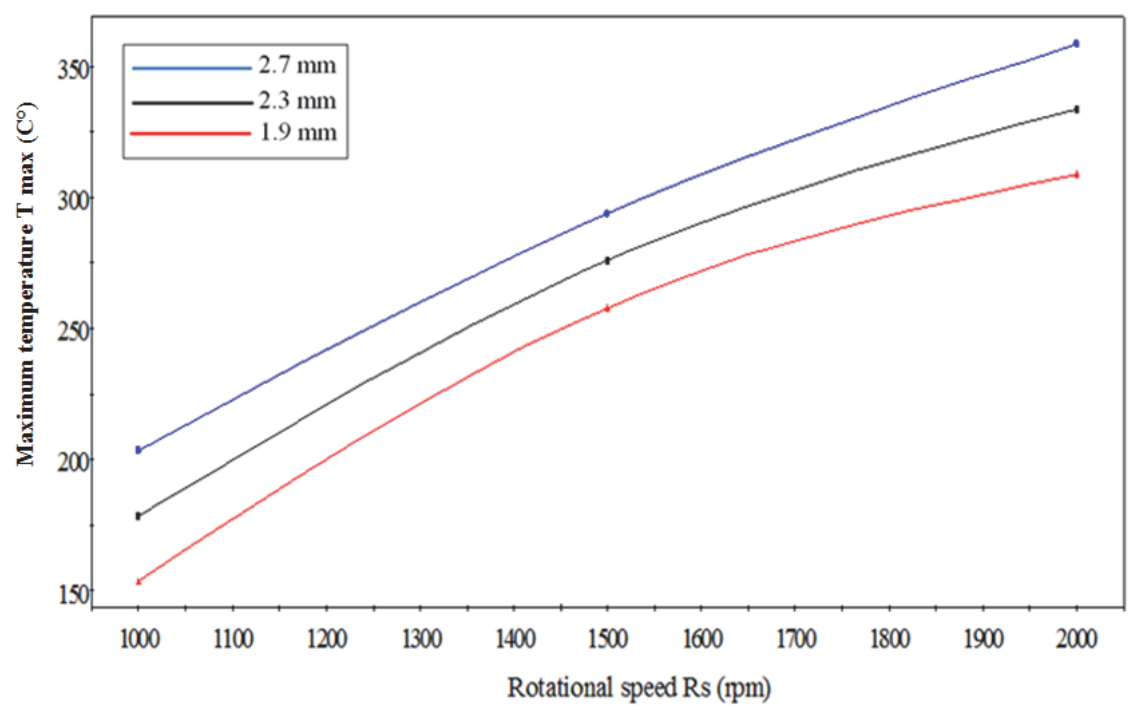

(b)

Figure 6: Analysis of thermal profile measured at the welding with MODDE 5.0 for (a) specimen welding with different tool rotating speed (b) specimen welding with different penetration depth.

\section{Tensile strength test}

The aim of this phase is to study the tensile stress-shear on plates welded by friction stir spot welding FSSW and the determination of the optimum parameters on specimens welded by a welding point.

Fig.7 presents the tensile curves (load- displacement) of structure welded by friction stir spot welding (FSSW) assembly with 1 point. Fig. 7 (A) present the tensile curves of structure welded by penetration depth fixed in $2.5 \mathrm{~mm}$ and three different 
rotational speed $\left(R_{S}=1000,1400\right.$ and $\left.2000 \mathrm{rpm}\right)$. It can be seen the best performing sample was that with $\mathrm{R}_{\mathrm{S}}=1400 \mathrm{rpm}$ at $2925 \mathrm{~N}$. The worst performing sample was that which has welding parameters of $\mathrm{R}_{\mathrm{S}}=1000 \mathrm{rpm}$ with $900 \mathrm{~N}$. We observe that the resistance of a welded point by FSSW depends on the tool rotation speed and this is proportional. Fig.7(B) show the tensile curves of load-displacement of welds made by friction stir spot welding (FSSW) assembles with a rotation speed $1400 \mathrm{rpm}$ and different penetration depth $\left(\mathrm{D}_{\mathrm{P}}=1.9 ; 2.3\right.$ and $\left.2.7 \mathrm{~mm}\right)$. It is observed that the parameters $\mathrm{D}_{\mathrm{P}}=2.7 \mathrm{~mm}$ gives the best tensile strength with $3322 \mathrm{~N}$, and the weakest tensile strength was obtained for $\mathrm{D}_{\mathrm{P}}=1.9 \mathrm{~mm}$. From these results we can observe the influence of the penetration depth $\mathrm{D}_{\mathrm{P}}$ on the mechanical behaviour of the joints welded by (FSSW).

According the analysis done with MODDE 5.0 for the tensile curves (load- displacement) of the structures welded by FSSW, the widening while taking into account the interaction between two parameters ( penetration depth and rotational speed). We can be seen in Fig.8 (A) that the maximal values of the maximal load correspond to the values between 1380 rpm and $1510 \mathrm{rpm}$, The contours in Fig.8 (B) show the effects of the different parameters on the load-displacement of the specimens joined by FSSW process.
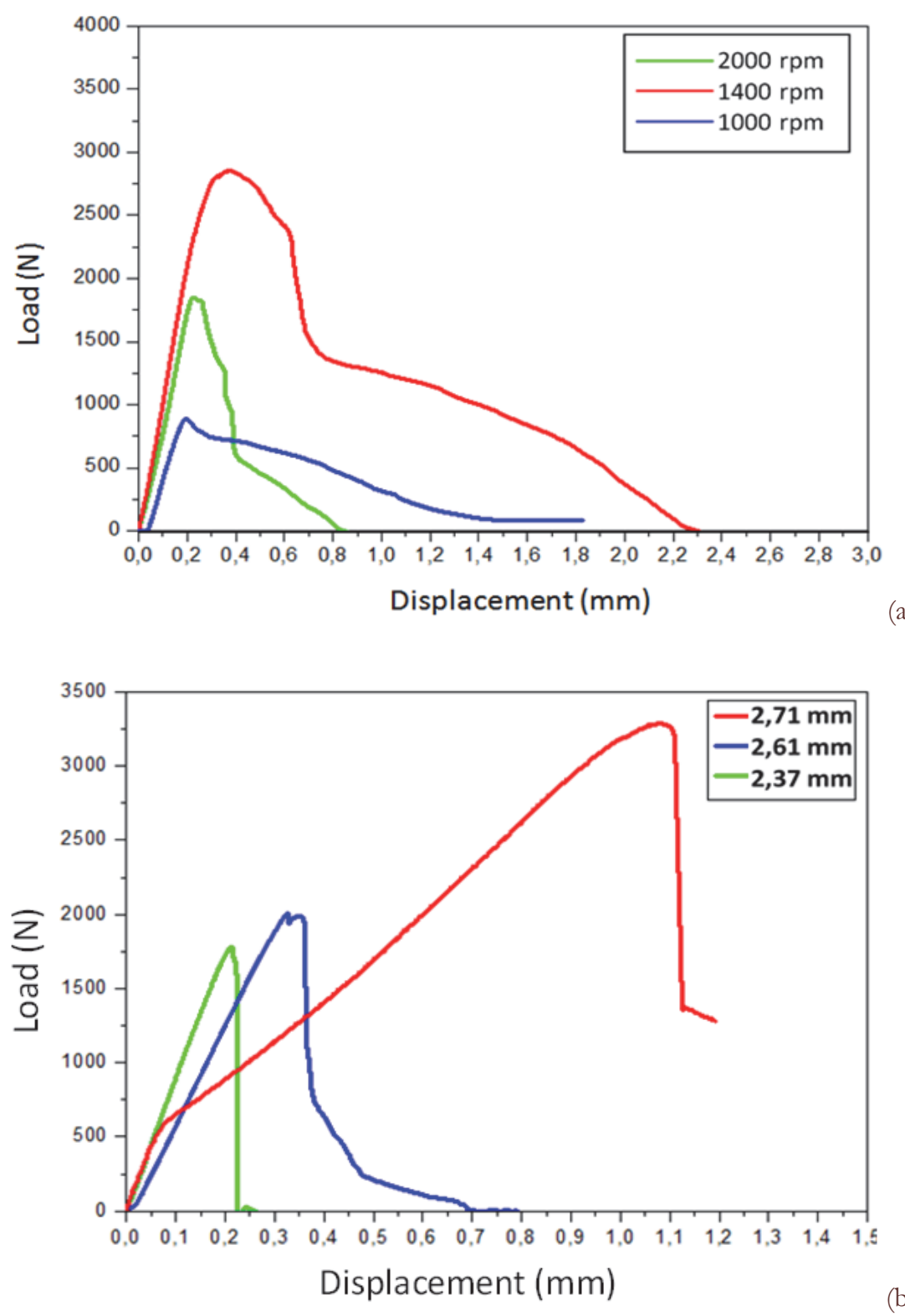

(a)

Figure 7: Typical load curve- Displacement (assembly with 1 point) (a) $D_{P}\left(2.5 \mathrm{~mm}\right.$ ) Different rotation speed (rpm) (b) $R_{S}(1400 \mathrm{rpm})$ different penetration depth $(\mathrm{mm})$. 

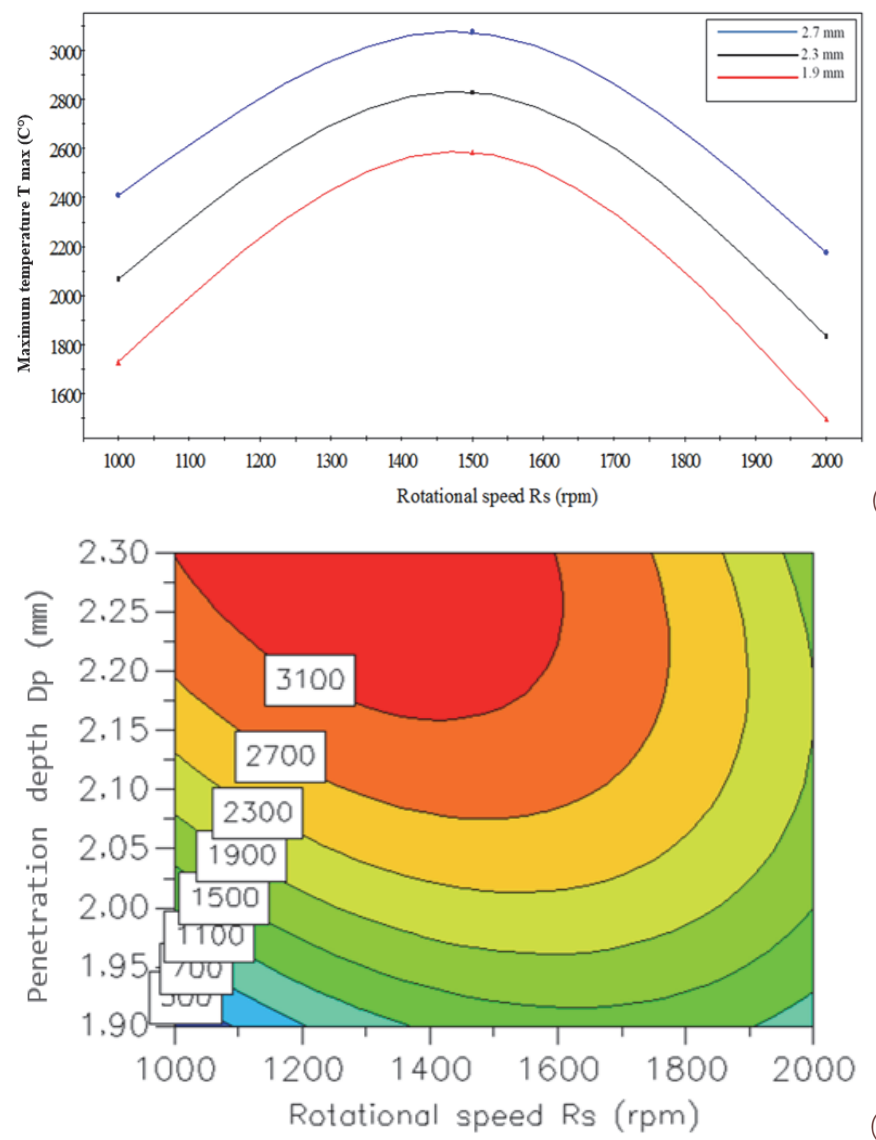

(a)

Figure 8 : Analysis with MODDE 5.0 of the tensile curves (load- displacement) of the structures welded by FSSW (a). The tensile curves with different parameters (b) Effects of the different parameters on the load-displacement.

\section{Microbardness}

Fig.9 present the method used for the microhardness measurements on three cross sections (A,B and C) of FSSW welded with different parameters, The results of the microhardness tests are presented in fig.10, When the results on BM of the Aluminum alloy 6061 T5 and Galvanized steel is approximately $56 \mathrm{HV}$ and $190 \mathrm{HV}$ respectively. Minimum hardness values in the Aluminum alloy have been found at the TAZ/ TMAZ regions with values varying from $35 \mathrm{HV}$ to $65 \mathrm{HV}$ depending on the FSSW parameters used. In the AA $6061 \mathrm{Al}$ alloy, Hardness was always higher at the BM; SZ hardness values have varied between $65 \mathrm{HV}$ and $90 \mathrm{HV}$. In the lower sheet Galvanized steel, SZ hardness has varied between $250 \mathrm{HV}$ and 740 $\mathrm{HV}$, whereas slightly higher hardness values than those observed in the BM have been found in the transition region TAZ/ TMAZ (between $150 \mathrm{HV}$ and $220 \mathrm{HV}$ ). These values are consistent with the cartography found at the SZ and transition zone TAZ/TMAZ under all conditions.

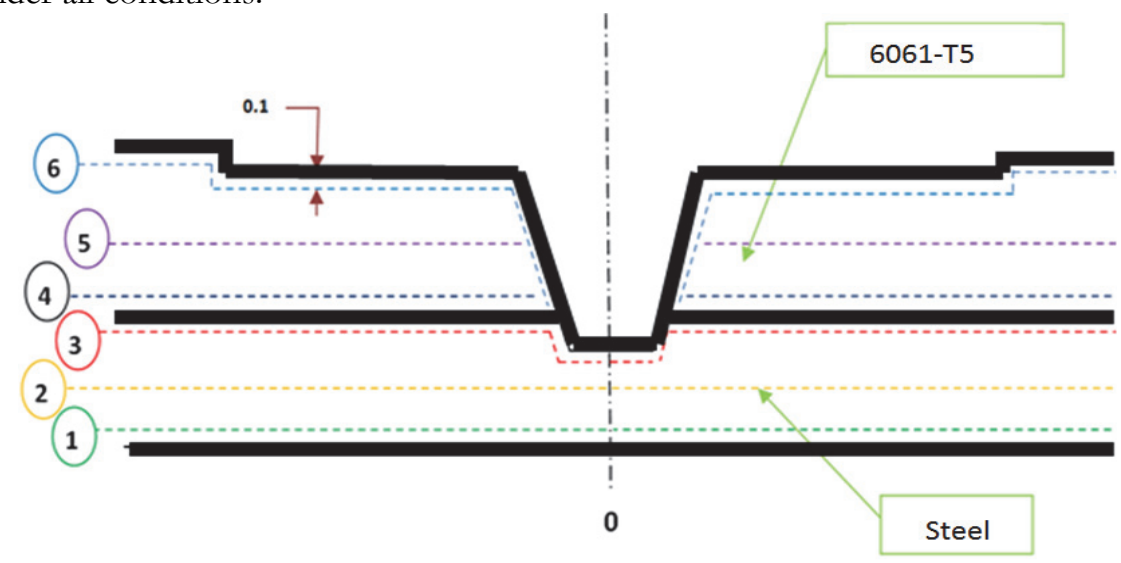

Figure 9:Schematic illustration of the Method of the microhardness measurements. 

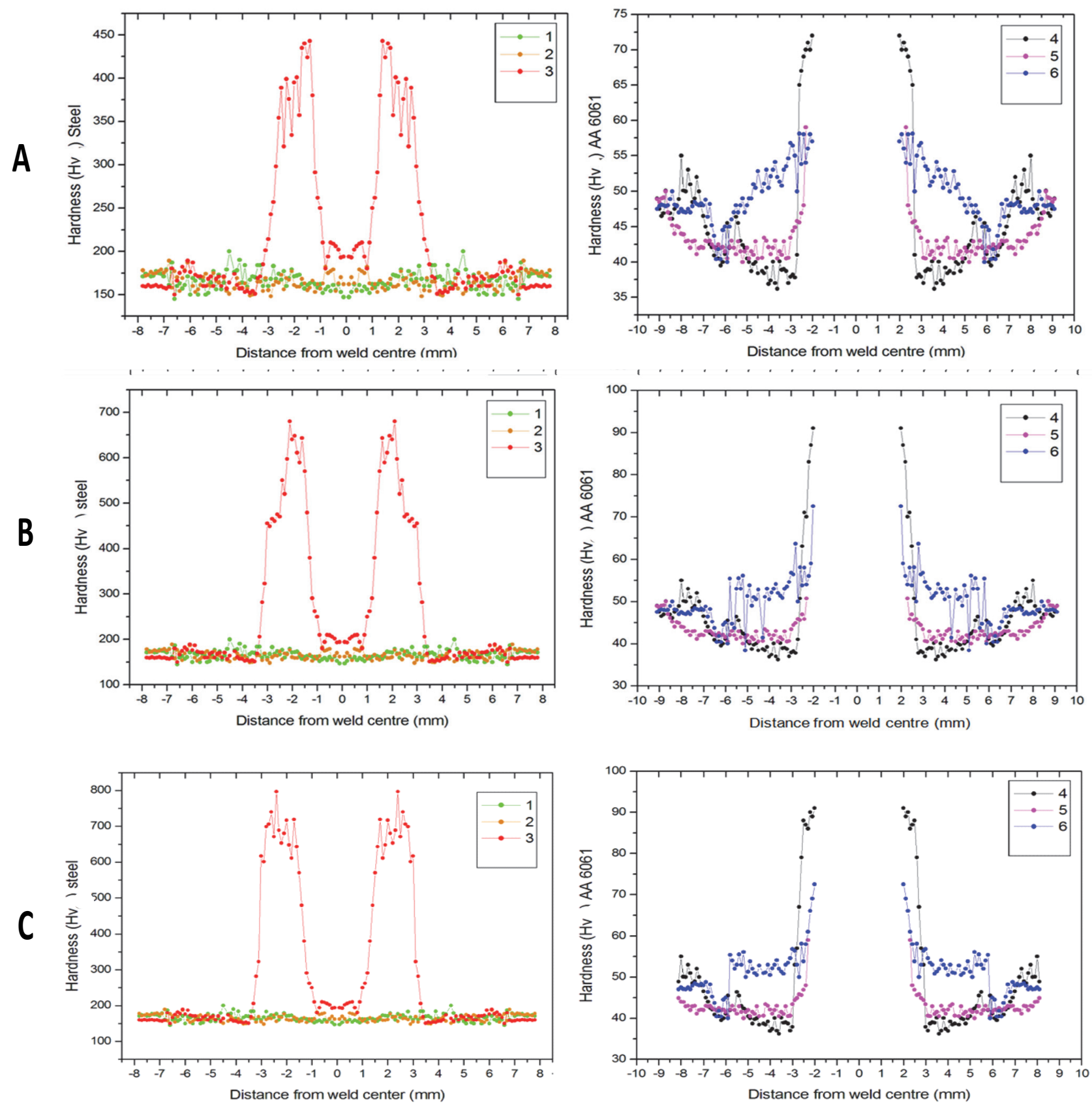

Figure 10:Microhardness profiles of cross-sections of dissimilar FSSW between AA 6061 and Galvanised steel (a) (RS 1000 rpm and DP $1.9 \mathrm{~mm}$ ); (b) ( $\mathrm{R}_{\mathrm{S}} 1000 \mathrm{rpm}$ and $\mathrm{D}_{\mathrm{P}} 2.7 \mathrm{~mm}$ ); (c) (Rs $2000 \mathrm{rpm}$ and $\left.\mathrm{D}_{\mathrm{P}} 2.7 \mathrm{~mm}\right)$.

The graphic exploitation of the results of measurements of the microhardness is carried out on the Tecplot software Fig.11. From Fig.11 is possible to observe that under conditions with higher $\mathrm{D}_{\mathrm{P}}(\mathrm{A}$ and B) higher SZ hardness have been obtained. The $\mathrm{R}_{\mathrm{S}}$ also plays an important role in the hardness behavior, higher $\mathrm{R}_{\mathrm{S}}(\mathrm{B}$ and $\mathrm{C}$ ) has resulted in higher $\mathrm{SZ}$ hardness values. High results of microhardness tests is on the rise of galvanized steel in the sheet of aluminum AA 6061. However, care must be taken while analysing the influence of higher $D_{P}$ since excessive penetration of the tool could cause excessive thinning of the upper sheet leading to a decrease in the weld strength. 

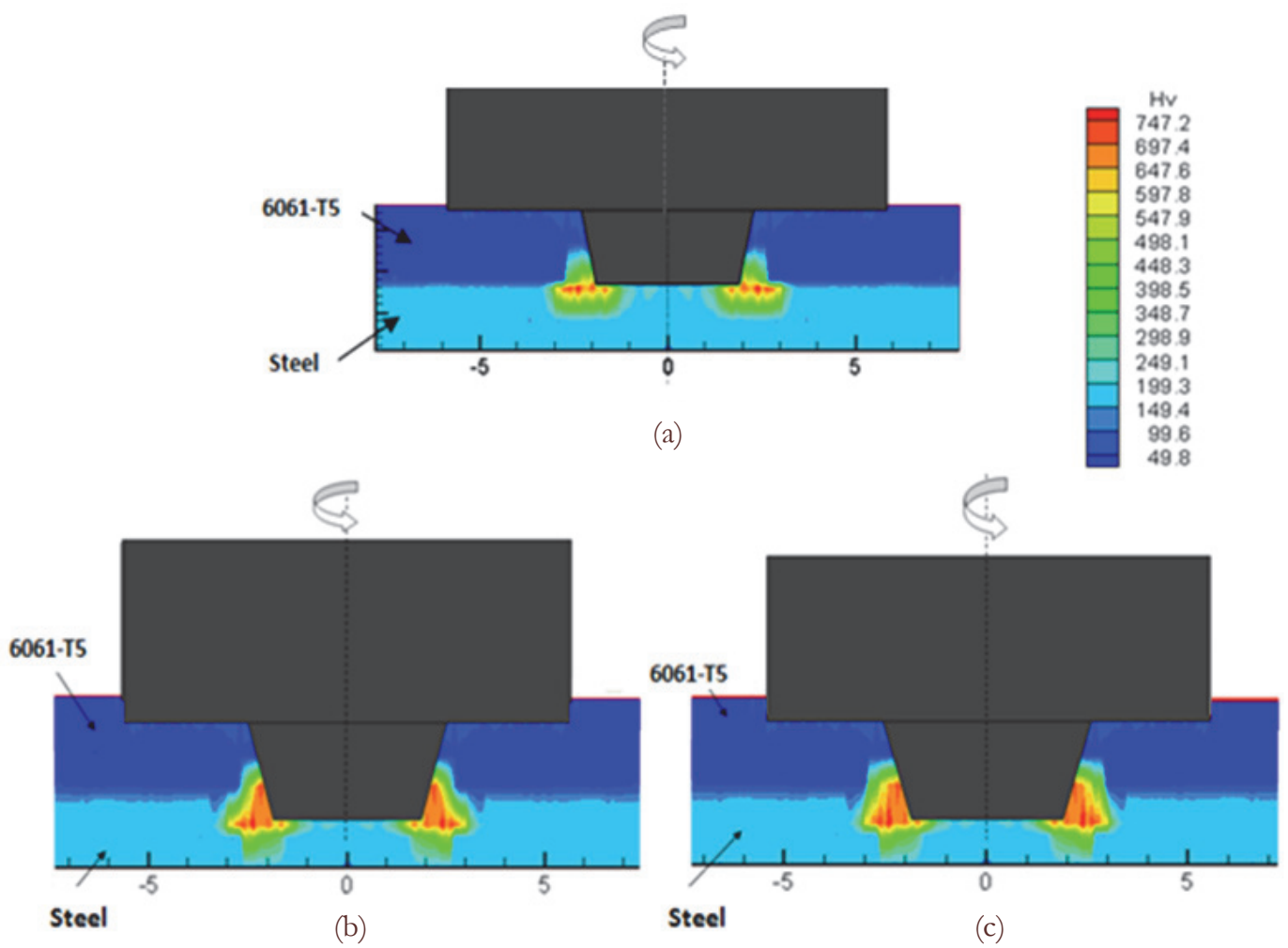

Figure 11 :Cartography of Microhardness profiles of cross-sections of dissimilar FSSW between AA 6061 and Galvanised steel; (a) (Rs $1000 \mathrm{rpm}$ and $\mathrm{D}_{\mathrm{P}} 1.9 \mathrm{~mm}$ ); (b) ( $\mathrm{R}_{\mathrm{S}} 1000 \mathrm{rpm}$ and $\mathrm{D}_{\mathrm{P}} 2.7 \mathrm{~mm}$ ); (c) ( $\mathrm{R}_{\mathrm{S}} 2000 \mathrm{rpm}$ and $\mathrm{D}_{\mathrm{P}} 2.7 \mathrm{~mm}$ ).
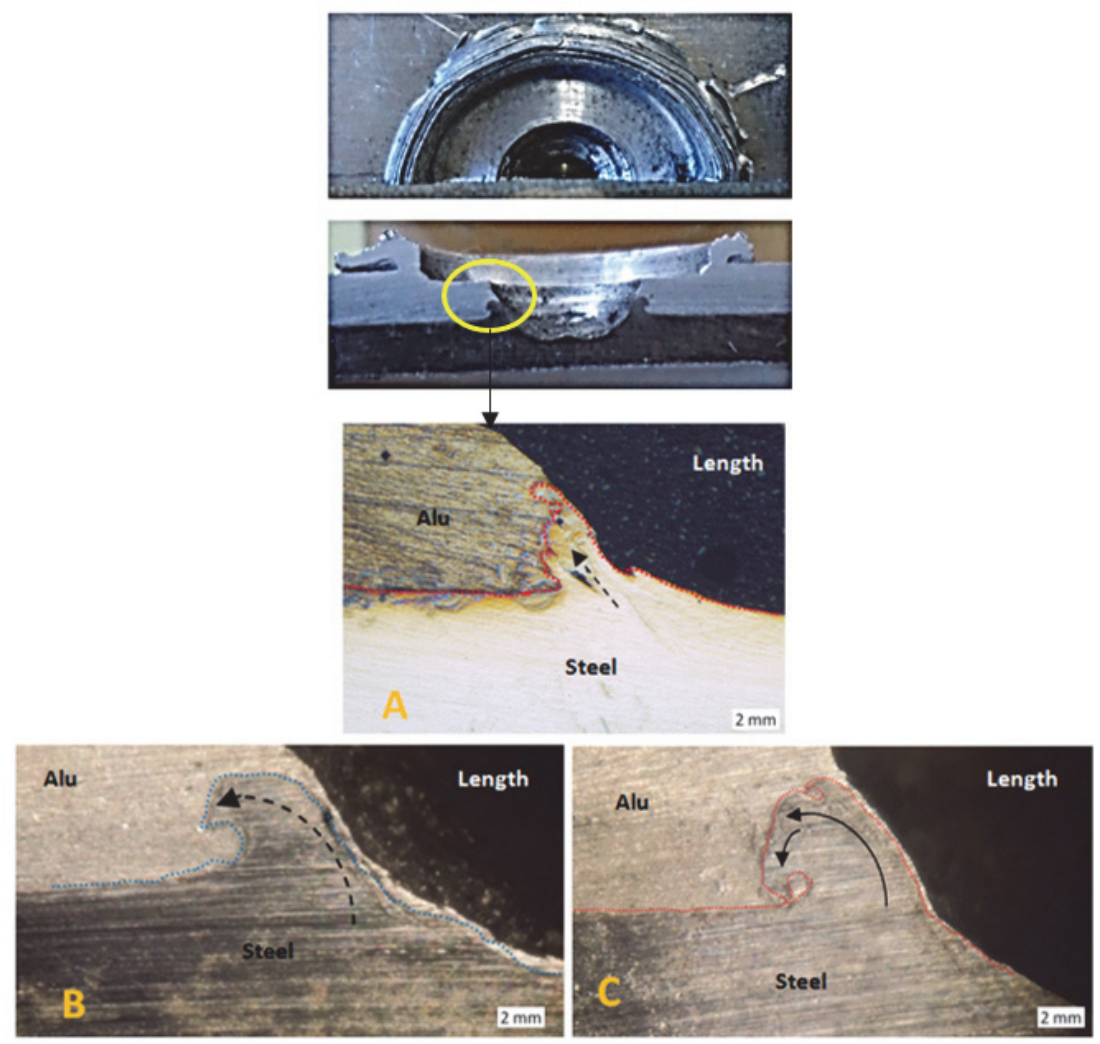

Figure 12: Optical micrographs of cross-sections of dissimilar FSSW between AA 6061 and galvanized steel (a) (Rs $1000 \mathrm{rpm}$ and $\mathrm{D}_{\mathrm{P}} 1.9$ $\mathrm{mm}$ ); (b) (Rs 1000 and $\mathrm{D}_{\mathrm{P}} 2.7 \mathrm{~mm}$ ); (c) ( $\mathrm{R}_{\mathrm{S}} 2000 \mathrm{rpm}$ and $\mathrm{D}_{\mathrm{p}} 2.7 \mathrm{~mm}$ ). 


\section{Microstructural characterisation}

Macrostructural characterisation has been performed under all FSSW conditions in Fig.12. It can be clearly observed that in all FSSW connections a large effective weld area has been achieved with no separation of upper and lower sheets in areas close to the keyhole. The upper surface of the joint is characterised by a small decrease in thickness originated by the deformation imposed by the tool shoulder (Fig.12 (A)). One can see that the steel is displaced upwards penetrating the Al sheet forming a mechanical interlocking between both materials (Fig.12 (B)) and for tool rotationel speed of $2000 \mathrm{rpm}$ are forming a larger mechanical interlocking in Fig.12(C). The size of this secondary flash changes according to the FSSW parameters (larger flash is associated with higher $\mathrm{R}_{\mathrm{S}}$ and $\mathrm{D}_{\mathrm{P}}$ ). It is also possible to observe that both $\mathrm{R}_{\mathrm{S}}$ and $\mathrm{D}_{\mathrm{P}}$ for the studied range have influenced the size (total area) of the transformed or stir zone (SZ). Higher $\mathrm{R}_{\mathrm{S}}$ and $\mathrm{D}_{\mathrm{P}}$ have resulted in larger SZ.

\section{CONCLUSION}

$\mathrm{D}$ issimilar FSSW between 1,5 mm thick AA $6061 \mathrm{Al}$ alloy and 1,7 mm thick Galvanized steel has been investigated. The following conclusions can be drawn.

1. Sound FSSW connections have been produced using a combination of different joining parameters ( $\mathrm{D}_{\mathrm{P}}$ and $\mathrm{R}_{\mathrm{S}) \text {. }}$

2. Shear failure load has increased with increasing both tool $R_{S}$ and $D_{P}$ depth for all FSSW connections. Higher $D_{P}$ has improved the mechanical interlocking between lower and upper sheet due to the formation of a larger secondary flash. 3. The $D_{p}$ and $R_{S}$ also plays an important role in the hardness behaviour, higher $D_{p}$ higher $S Z$ hardness higher $R_{S}$ has resulted in higher SZ hardness values.

\section{RÉFÉRENCES}

[1] James, M. and Mahoney, M. (1999). Prc.1st International on friction stir welding, Thousand Oaks, USA, California.

[2] Skrotzki, B. and Mucken, J. (2001). Proceedings from Materials Solutions Conference, IN, ASM International., Indianapolis.

[3] da Silva, A. A., Aldanondo, E., Alvarez, P., Arruti, E. and Echeverr, A. (2010). Friction stir spot welding of AA 1050 $\mathrm{Al}$ alloy and hot stamped boron steel (22MnB5), Journal Science and Technology of Welding and Joining, 15, pp. 682687.

[4] Badarinarayan, H., Hunt, F. and Okamoto, K. (2007). Friction stir spot welding, In: R.S. Mishra, M.W. Mahoney (Eds.), Friction stir welding and processing, ASM International, Ohio, pp. 235-272.

[5] Merzoug, M., Mazari, M., Berrahal, L. and Imad, A. (2010). Parametric studies of the process of friction spot stir welding of aluminium 6060-T5 alloys, Materials \& Design., 31, pp. 3023-3028.

[6] Tozaki, Y., Uematsu, Y. and Tokaji, K. (2007). Effect of tool geometry on microstructure and static strength in friction stir spot welded aluminium alloys, International Journal of Machine Tools and Manufacture, 47, pp. 2230-2236.

[7] Tozaki, Y., Uematsu, Y. and Tokaji, K. (2010). A newly developed tool without probe for friction stir spot welding and its performance Journal of Materials Processing Technology, 210, pp. 844-851.

[8] Badarinarayan, H., Shi, Y., Li, X. and Okamoto, K., (2009). Effect of tool geometry on hook formation and static strength of friction stir spot welded aluminum 5754-O sheets, International Journal of Machine Tools \& Manufacture., 49, pp. 814-823.

[9] Herbelot, C., Hoang, T.D., Imad, A.N., Benseddiq, N. (2010). Damage mechanisms under tension-shear loading in a friction stir spot welding (FSSW)., Journal Science and Technology of Welding and Joining, 15, pp. 688-693.

[10] Thomas, W.M., Johnson K. and Wiesner, C. S. (2003) friction stir welding -recent devlompments in tool and process technology, AEM., 5, pp. 485-490.

[11] Sakano, R., Murakami, K., Yamashita, K., Hyoe, T., Fujimoto, M., Inuzuka, M., Nagao, Y. and Kashiki, H. (2001). Development of spot FSW robot system for automobile body members. Proceedings of 3rd International Symposium of Friction Stir Welding.

[12] Mitlin, D., Radmilovic, V., Pan, T., Chen, J., Feng, Z., and Santella. M.L. (2006). Structure-properties relations in spot friction welded (also known as friction stir spot welded) 6121 aluminum. Mat SciEng A., 441, pp. 79-96. 
[13] Yin, Y.H., Ikuta, A. and North, T.H. (2010). Microstructural Features and Mechanical Properties of AM60 and AZ31 Friction Stir Spot Welds., 61, pp. 1018-1028.

[14] Iwashita, T. (2003). Method and apparatus for joining, US patent, 6, pp. 601-751.

[15] Badarinarayan, H. F. and Okamoto K. (2007). In: Friction stir welding and processing, R. S. Mishra and M. W. Mahoney (Eds.), Materials Park, OH, ASM International, pp. 235-272.

[16] Torkamany, M. J., Tahamtan, S. and Sabbaghzadeh, J. (2010). Dissimilar welding of carbon steel to 5754 aluminum alloy by Nd: YAG pulsed laser, Mater. Des., 31, pp.458-465.

[17] Lin, S.-B., J.-L.Song, G.-C.Ma and C.-L. Yang, (2009). Dissimilar metals TIG welding-brazing of aluminum alloy to galvanized steel, Front. Mater. Sci. Chin., 3, pp. 78-83.

[18] Roulin, M., Luster, J. W., Karadeniz, G. and Mortensen, A.: (1999). Strength and fracture of furnace-brazed joints between aluminum and stainless steel, Weld. J., 78, pp. 151-155.

[19] Yilmaz, M. and Acet, M.: (2003). Interface properties of aluminum/steel friction-welded components, Mater. Charact., 49, pp. 421-429.

[20] Ikeuchi, K., Takahashi, M., Watanabe, H. and Aritoshi, M.. (2009). Effect of C content on intermetallic compound layer and joint strength in friction welding of $\mathrm{Al}$ alloy to steel, Welding in the World, 53, pp.135-139.

[21] Elliot, S. and Walllach, E. R. (1981). Joining aluminium to steel., 3, pp. 167-171.

[22] Aizawa, T., Kashani, M. and Okagawa, K. (2007). Application of magnetic pulse welding for aluminum alloys and SPCC steel sheet joints, Weld. J., 86, pp. 129-124.

[23] Watanabe, T., Sakuyama, H. and Yanagisawa, A. (2009). Ultrasonic welding between mild steel sheet and Al-Mg alloy sheet, J. Mater. Process. Technol., 209, pp. 5475-5480.

[24] Abe, Y., Kato, T. and Mori, K. (2006). Joinability of aluminium alloy and mild steel sheets by self piercing rivet, J. Mater. Process. Technol., 177, pp. 417- 421.

[25] Pfestorf, M. (2005). Manufacturing of high strength steel and aluminum for a mixed material body in white, Adv. Mater. Res., 8, pp. 109-124.

[26] Umetrics AB, MODDE 5.0. User Guide and Tutorial, Umetrics, Umea, Sweden., (1999).

[27] Susmel, L., Hattingh, D. G., James, M. N., Maggiolini, E. and Tovo, R. (2015). Designing aluminium friction stir welded joints against multiaxial fatigue, Frattura ed Integrità Strutturale, 37, pp. 207-214.

[28] Patil, C., Patil, H. and Patil, H. (2016). Experimental investigation of hardness of FSW and TIG joints of Aluminium alloys of AA7075 and AA6061, Frattura ed Integrità Strutturale, 37, pp. 325-332.

[29] Abe, T., Akebono, H., Kato, M. and Sugeta, A. (2016). Fatigue properties and fracture mechanism of load carrying type fillet joints with one-sided welding, Frattura ed Integrità Strutturale, 35, pp.196-205

[30] van Lieshout, P.S., den Besten, J.H. and Kaminski, M.L. (2016) Comparative study of multiaxial fatigue methods applied to welded joints in marine structures, Frattura ed Integrità Strutturale., 37, pp. 173-192. 